skulle finnes, så er relevansen av hendelsene i 2010-2011 for evalueringen av den norske beslutningen i 2009 likevel neglisjerbar. Massevaksinasjon i 2009 var begrunnet med at den enkelte skulle tilbys beskyttelse mot den umiddelbart forestående pandemien, ikke med at massevaksinasjonen skulle beskytte mot neste års sesonginfluensa. Til slik beskyttelse var en konvensjonelt tilpasset sesonginfluensavaksine med velavklart risikoprofil langt å foretrekke for risikoutsatte individer.

I et tidligere innlegg har jeg gjort greie for hva jeg legger i utsagnet illegitim bruk av frykt (1). I innlegget henviste jeg til en referanse der helsedirektøren gjorde det klart at han fant det nødvendig å oppjustere frykten i befolkningen (2). Gitt kunnskapen vi på det tidspunktet satt inne med, burde frykten vært ned- heller enn oppjustert. Også det «kunststykket» klarte de å få til i Danmark.

\section{Elling Ulvestad}

elling.ulvestad@helse-bergen.no

Elling Ulvestad (f. 1958) er professor og avdelingssjef ved Mikrobiologisk avdeling, Haukeland universitetssykehus.

Ingen oppgitte interessekonflikter.

Litteratur

1. Ulvestad E. Re: Jakten på det utenomjordiske. Tidsskr Nor Legeforen 2014 134: 1636

2. Kråkenes C. Myndighetene ville kommunisere usikkerhet. NRK 9.3.2010. www.nrk.no/fordypning/myndighetene-onsket-usikkerhet-1.7030193 (3.10.2014)

\section{Re: Kjendisforeleseren}

Fingeren til Trond Viggo Torgersen har fătt mye omtale, og nevnes også i Edvin Scheis portrettintervju «Kjendisforeleseren» (1).

På Anatomen omkring 1958 anbefalte vår professor, Johan Torgersen, oss studenter å stikke en finger i rektum, lukke øynene og tenke på alle de flotte organene som befant seg i fingerens umiddelbare nærhet!

\section{Arne C. Jørgensen}

ac.j2@online.no

Arne C. Jørgensen (f. 1939) er lege.

Ingen oppgitte interessekonflikter.

\section{Litteratur}

1. Schei E. Kjendisforeleseren. Tidsskr Nor Legeforen 2014; 134: 1462-5.

\section{Re: Når legen finner narkotika}

I dommen fra Høyesterett som omtales i denne artikkelen blir legens forspillelse av bevismateriale ansett som «rettslig holdbar ivaretakelse av taushetsplikten» (1). Her ser jeg at det vil komme mye «sivil ulydighet». Jeg ønsker ikke å være behjelpelig med å skjule kriminell virksomhet for politiet. Helsevesenet kan da umulig ta part for den organiserte kriminalitet mot de som skal verne samfunnet mot de kriminelle.

\section{Nils Håvard Dahl}

nils.h.dahl@hnt.no

Nils Håvard Dahl (f. 1953) er avdelingsoverlege ved sykehuset i Levanger. Ingen oppgitte interessekonflikter.

\section{Re: Når pasienten nekter blodoverføring}

Som Rolf Furuli (1) ble jeg meget overrasket over lovforståelsen Bahus og Førde presenterer i kronikken «Når pasienten nekter blodoverføring» (2).

Helsepersonelloven (hpl.) § 7 regulerer helsepersonells inngrepsplikt dersom pasienten er i en akutt nødssituasjon og hjelpen åpenbart er påtrengende nødvendig for å hindre livstruende følger.

Bestemmelsene som er samlet i pasient- og brukerrettighetsloven (pbrl.) § 4-9, suspenderer i nærmere bestemte situasjoner denne inngrepsplikten. Den gjør det samtidig urettmessig for helsepersonell å gripe inn i pasientens rett til å nekte behandling i gitte tilfeller, også når nødrettssituasjoner blir en realitet. Dette framgår klart av ordlyden i hpl. $\S 7$ første ledd.

Bestemmelsen ble vedtatt i Stortinget mot stemmene til Fremskrittspartiet, som ønsket en lovfestet inngrepsplikt i de situasjonene som er nevnt i første ledd.

Det er videre oppstilt et krav om at det må foreligge en «alvorlig overbevisning»; dette innebærer ikke et krav om bestemt begrunnelse. Men det må stilles krav om både en viss fasthet og varighet. Overbevisningen må videre framstå som et uttrykk for en selvvalgt og rasjonell forestilling, og ikke for eksempel som et uttrykk for en alvorlig sinnslidelse. Dersom helsepersonell er i tvil om dette, kan de ikke unnlate å gi hjelp etter hpl. § 7. Dessuten må «nekteren» være over 18 år (tidligere «myndig»).

Dersom legen tidsmessig kan utsette behandlingen av en pasient som nekter å motta blodoverføringer, må legen ta stilling til om han eller hun selv kan behandle pasienten også når pasienten nekter å motta blod. Dersom helsepersonellet godtar dette, skal pasienten ikke gis blod eller blodprodukter, heller ikke hvis pasienten risikerer å dø av blodtap. Kan helsepersonellet ikke godta å behandle pasienten på slike vilkår, bør pasienten om mulig henvises til annet helsepersonell. Det er ikke regelfestet en reservasjonsrett som i abortloven $\S 14$, men det er grunn til å oppsøke helsepersonell som uten alvorlige problemer kan akseptere pasientens rett til å nekte blodtransfusjoner.

Bestemmelsen innebærer videre at helsepersonell ikke er strafferettslig ansvarlig dersom pasienten skades ytterligere eller dør som følge av (den manglende) behandlingen.

Foreldre har ingen tilsvarende mulighet til å avslutte eller avslå nødvendig helsehjelp, herunder blodtansfusjoner, til sine barn pga. sin egen alvorlige overbevisning. Her gir hpl. § 7 tilstrekkelig inngrepshjemmel, og også en inngrepsplikt, når helsehjelpen er «påtrengende nødvendig» (3).

Det er pussig at Bahus og Førde prøver å (bort)fortolke klare lovbestemmelser ut fra etiske prinsipper. Bestemmelsen i § 4-9 er nettopp ment å sikre pasienter mot legers overstyring ut fra egne oppfatninger og vurderinger. Dette var tydeliggjort i forarbeidene og fikk bred tilslutning i Stortinget. Da hjelper det ikke å dekke seg bak jussprofessorer, i dette tilfellet Marit Halvorsen. Det gjør ikke bortfortolkningene bedre.

\section{Aslak Syse}

aslak.syse@jus.uio.no

Aslak Syse (f. 1946) er professor ved Universitetet i Oslo

Ingen oppgitte interessekonflikter.

\section{Litteratur}

1. Furuli RJ. Re: Når pasienten nekter blodoverføring. Tidsskr Nor Legeforen 2014 134: 1728 .

2. Bahus M, Førde R. Når pasienten nekter blodoverføring. Tidsskr Nor Legeforen 2014: 134: $850-1$

3. Syse A, Befring AK. Barn kan få blod uten foreldres samtykke. Tidsskr Nor Lægeforen 2003; 123: 2477

\title{
Litteratur
}

1. Duvaland L. Når leger finner narkotika. Tidsskr Nor Legeforen 2014; 134 : $1676-8$ 